\title{
Recommendations for Control and Mitigation of Laurel Wilt and Ambrosia Beetle Vectors in Commercial Avocado Groves in Florida ${ }^{1}$
}

\author{
Jonathan H. Crane, Daniel Carrillo, Edward A. Evans, Romina Gazis, Bruce Schaffer, Fredy \\ Ballen, and Jeff Wasielewski
}

\section{Introduction of Laurel Wilt}

The redbay ambrosia beetle, Xyleborus glabratus, and its fungal symbiont, Raffaelea lauricola ( $R f)$, were introduced into Port Wentworth, Georgia, USA, in infested wood packing material from Asia during 2002 (Mayfield and Thomas 2006). This insect-disease complex, commonly called laurel wilt (LW), affects trees in the Lauraceae family and spreads through natural areas by redbay ambrosia beetle movement and anthropogenic movement of infested wood products (e.g., firewood, wood-turners wood, and BBQ smoke-wood). Plant hosts of the redbay ambrosia beetle- $R f$ complex include at least ten native lauraceous woody species (e.g., redbay [Persea borbonia] and swampbay $[P$. palustris]) in Florida, as well as non-native species such as camphor (Cinnamomum camphora), avocado ( $P$. americana), and potentially California bay (Umbellularia californica) (Campbell et al. 2017; Dreaden et al. 2016; Fraedrich 2008; Fraedrich et al. 2008; Fraedrich et al. 2011; Fraedrich et al. 2015; Hughes et al. 2012; Hughes et al.
2013; Hughes et al. 2014; Mayfield et al. 2013; Ploetz and Konkol 2013). By February 2010, redbay ambrosia beetles were detected in a natural area 21 miles $(33.7 \mathrm{~km})$ north of the south Florida avocado production area (125 sq. miles; 324 sq. km) in Miami-Dade County (Thomas 2010; Ploetz et al. 2011a). In 2011, the first confirmed swampbay tree to succumb to LW was documented in this natural area, and by $2012 \mathrm{LW}$ was detected in a commercial avocado grove in Homestead, Florida (J. Crane, personal observation). Contrary to predictions, populations of $X$. glabratus did not establish in commercial avocado groves. However, laurel wilt is still prevalent and continues to spread as a result of an unexpected, uncommon lateral transfer of $R$. lauricola to native and exotic ambrosia beetles, which now function as secondary vectors of $R$. lauricola (Carrillo et al. 2014; Ploetz et al. 2017). At least two ambrosia beetles, Xyleborus volvulus and $X$. bispinatus, have been shown to transmit the laurel wilt pathogen to avocado groves (Carrillo et al. 2014). These ambrosia beetles are most active during dusk (from

1. This document is HS1360, one of a series of the Horticultural Sciences Department, UF/IFAS Extension. Original publication date March 2020. Visit the EDIS website at https://edis.ifas.ufl.edu for the currently supported version of this publication.

2. Jonathan H. Crane, professor and associate center director, Horticultural Sciences Department; Daniel Carrillo, assistant professor, Entomology and Nematology Department; Edward A. Evans, center director and professor, Food and Resource Economics Department; Romina Gazis, assistant professor, Plant Pathology Department; Bruce Schaffer, professor, Horticultural Sciences Department; Fredy Ballen, data management analyst, UF/IFAS Tropical Research and Education Center, Homestead, FL; and Jeff Wasielewski, Extension agent, UF/IFAS Extension Miami-Dade County, Homestead, FL 33030.

The use of trade names in this publication is solely for the purpose of providing specific information. UF/IFAS does not guarantee or warranty the products named, and references to them in this publication do not signify our approval to the exclusion of other products of suitable composition. Use pesticides safely. Read and follow directions on the manufacturer's label.

The Institute of Food and Agricultural Sciences (IFAS) is an Equal Opportunity Institution authorized to provide research, educational information and other services

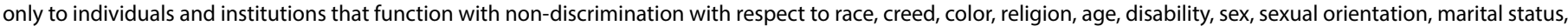
national origin, political opinions or affiliations. For more information on obtaining other UF/IFAS Extension publications, contact your county's UF/IFAS Extension office. U.S. Department of Agriculture, UF/IFAS Extension Service, University of Florida, IFAS, Florida A \& M University Cooperative Extension Program, and Boards of County Commissioners Cooperating. Nick T. Place, dean for UF/IFAS Extension. 
about 4 PM-8 PM) and generally fly $10 \mathrm{ft}(1.2 \mathrm{~m})$ or less from the ground (Menocal et al. 2018).

At present LW has been detected in 11 southeastern US states, including Alabama, Arkansas, Florida, Georgia, Kentucky, Louisiana, Mississippi, North Carolina, South Carolina, Tennessee, and Texas (Figure 1; US Forest Service 2019), and in all of Florida's 67 counties. Laurel wilt is now endemic in the avocado production area of Miami-Dade County. There is great risk for introduction of LW into California, Mexico, and Central and South America through natural spread of the redbay ambrosia beetle through natural areas and by movement of infested wood material (e.g., firewood) (Crane et al. 2015; Ploetz et al. 2011b).

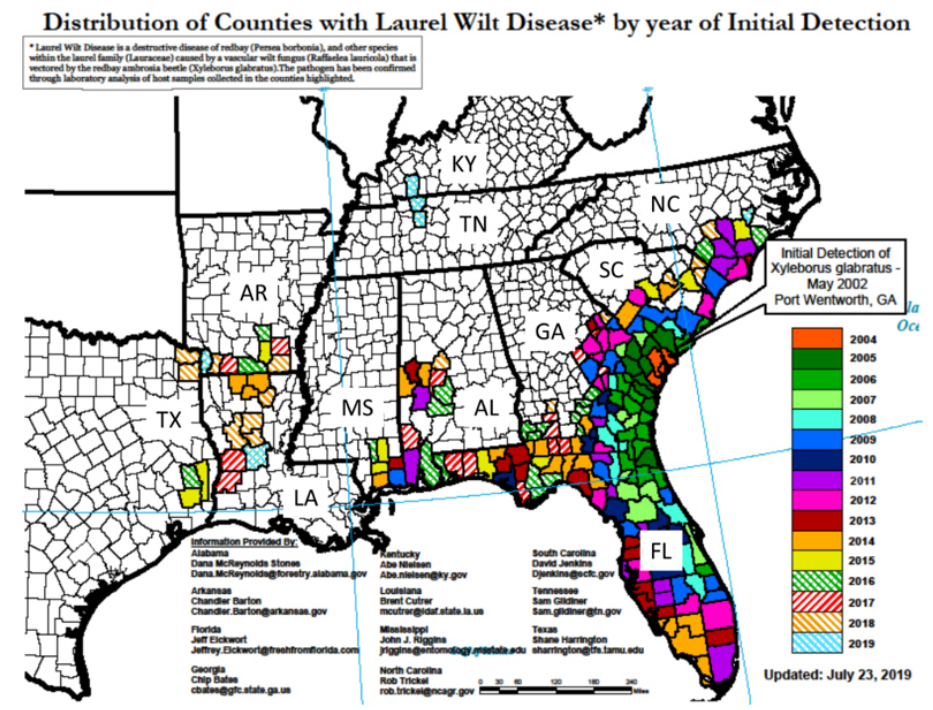

Figure 1. Map of current laurel wilt detection. Present in 11 southeastern US states, including Alabama, Arkansas, Florida, Georgia, Kentucky, Louisiana, Mississippi, North Carolina, South Carolina, Tennessee, and Texas. Credit: US Forest Service.

The LW susceptibility of 24 container-grown avocado cultivars of varied genetic backgrounds was tested, and those of Guatemalan × Mexican background (e.g., 'Hass', 'Winter Mexican') were less quickly affected by LW inoculation than avocado cultivars of Guatemalan $\times$ West Indian (e.g., 'Miguel') background, which were less quickly affected than West Indian (e.g., 'Simmonds' and 'Donnie') cultivars (Ploetz et al. 2011c). This suggests there may be some variability in how rapidly symptoms of LW progress dependent upon genetic background. In addition, symptom severity was positively correlated with plant size; larger plants declined more rapidly to infection by the LW pathogen than smaller plants.

In commercial groves, mature trees of 32 avocado cultivars of various genetic backgrounds have been documented to succumb to LW (Table 1) (A. Palmateer, R. Gazis, and J. Crane, personal observations). No mature avocado trees of any cultivar have been discovered to be tolerant to the LW pathogen so far. Recent greenhouse studies have shown that the rate of LW disease progression (i.e., the speed of symptoms development) is related more to the scion than the rootstock, but the rootstock does have some influence (B. Schaffer, personal observations). No tolerant scion or rootstock has been confirmed to date, but work is underway to try to identify LW-tolerant scions, rootstocks, and scion/ rootstock combinations.

In mature avocado groves, LW disease spreads by root grafts among adjacent trees and by ambrosia beetle (AB) infestations. Via root grafts the pathogen may move at a rate of three to six new trees per month; this can result in the loss of 90 or more trees in a six-month period (Crane et al. 2016; Ploetz et al. 2017). The visible external symptoms of laurel wilt disease in avocado begin as green-leaf wilting, typically in one section of the tree (Figure 2). Frass straws resulting from $\mathrm{AB}$ boring may be evident, and the sapwood often has blackish-blue-stained streaks. As the disease progresses, leaves desiccate, turn brown, and usually remain attached to the branches (for up to about 12 months), and tree dieback progressively takes over more sections of the tree. Occasionally, copious leaf drop occurs at the early stages of infection, but subsequently tree dieback and death commence (Figure 3 ). In both cases the tree eventually dies, although sometimes if the tree is left in place or is cut to a stump, it may regrow from the stump or large roots (Figure 4). There are conflicting reports regarding the recovery of LW-infected trees after stumping ( 4 ft; $\sim 1.2 \mathrm{~m}$ height). Some have reported trees regrow canopy and appear disease-free, but this regrowth may die back repeatedly until the tree is dead. Others have reported that stumped trees regrow their canopy and resume fruit production after two to three years. How frequently regrowth and fruit production resume are not known and are under evaluation.

\section{Research Findings Related to Current Control Strategies}

1. Laurel wilt is highly virulent, and trees inoculated with as little as 39 colony forming units (CFUs; spores) can cause the death of mature trees (R. C. Ploetz, unpublished data). The higher the number of CFUs, the more quickly the disease progresses. The pathogen moves rapidly within the xylem to new locations, causing the tree's defense mechanism (i.e., production of tyloses and gums to wall off the pathogen) to rapidly block the xylem water-conducting tissue and cause the death of the tree (Inch and Ploetz 2012; Inch et al. 2012). 


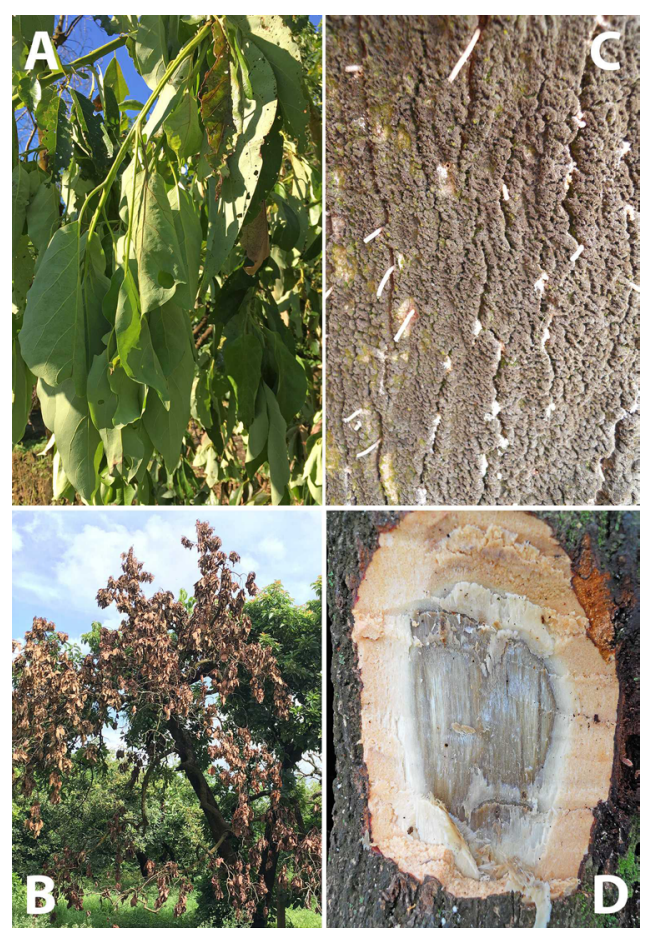

Figure 2. The visible external symptoms of laurel wilt disease begin as green-leaf wilting (A), typically in one section of the tree (B). Frass straws from $A B$ boring may be evident $(C)$, and the sapwood has blackish-brown-blue streaks (D).

Credits: J. H. Crane, UF/IFAS
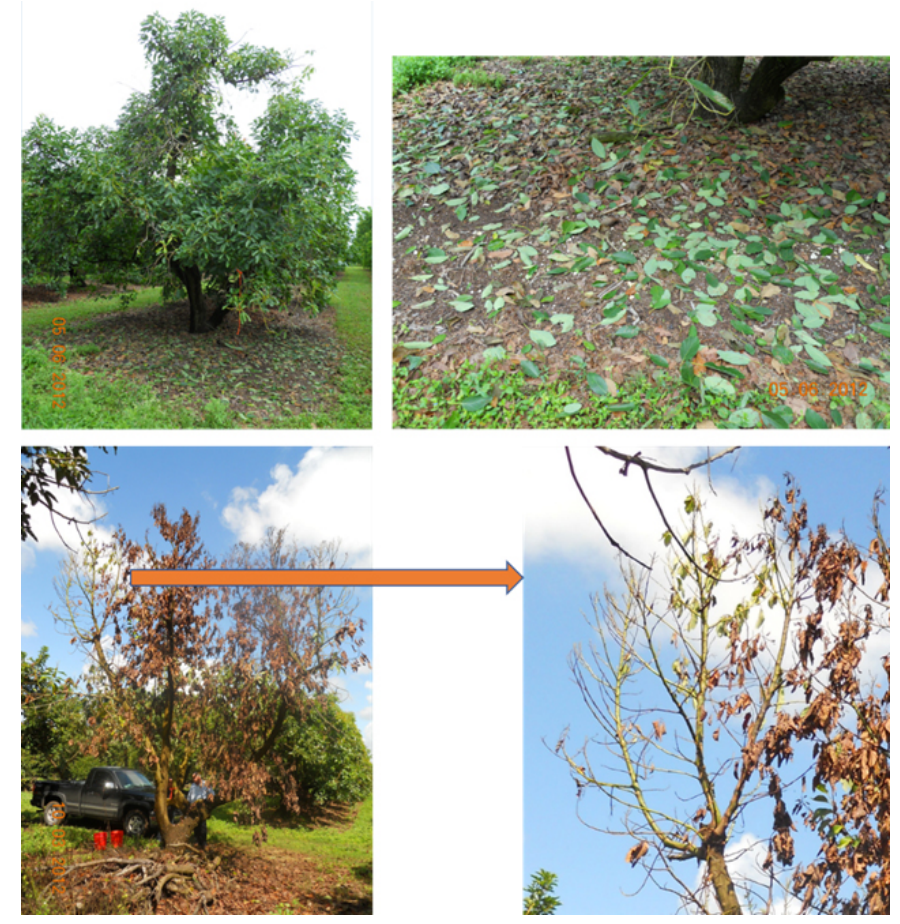

Figure 3. Mature LW-affected avocado trees with sections of the tree with copious leaf drop and other sections with leaves remaining on the stems prior to dieback and death.

Credits: J. H. Crane, UF/IFAS

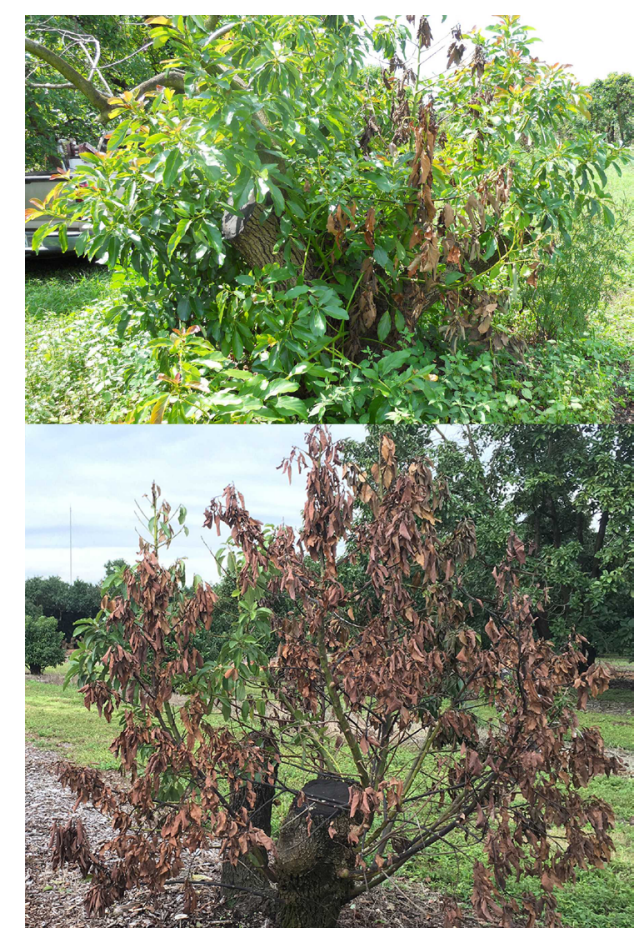

Figure 4. (A) Regrowth and some branch dieback of tree cut to a stump ( 1.2 m height), and (B) tree regrowth dies back repeatedly until the tree is dead.

Credits: J. H. Crane, UF/IFAS
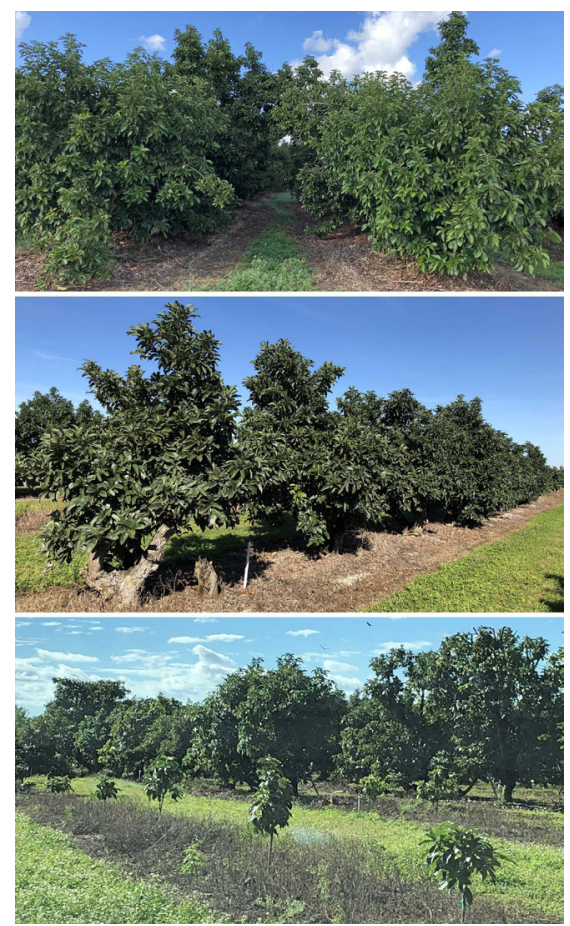

Figure 5. Light exposure of highly shaded (A), top-worked (B), and newly planted (C) areas of an orchard.

Credits: J. H. Crane, UF/IFAS

2. Previous recommendations based on research reported that prophylactic systemic propiconazole (Tilt $\left.{ }^{\circledR}\right)$ fungicide infusion protected avocado trees from LW for 12 to 18 months (Crane et al. 2016; Ploetz et al. 2011d). However, infusion of propiconazole fungicide is too 
costly and may cause physical damage to the trees by repeated applications (Evans et al. 2015). In contrast, prophylactic Tilt ${ }^{\circledR}$ injections are much less expensive and have been shown to prevent LW outbreaks in commercial avocado groves. Systemic movement of the fungicide throughout the tree from injection takes seven to eight months, and protection from LW has been reported to last 12-24 months, depending upon rate of fungicide, tree size, LW status of the grove at the time of injection, and LW history of the grove (Brooks Tropicals, personal communication).

\section{A number of conventional contact insecticides have} shown efficacy at controlling ambrosia beetles, including Malathion, Danitol ${ }^{\circledR}$, Agri-Mek ${ }^{\circledR S C}$, Talstar ${ }^{\circledR S}$, and Hero $^{\circledR}$ (nonbearing trees only) (Carrillo et al. 2013; Peña et al. 2011). However, these insecticides are only effective when the $A B$ is outside the tree, and $A B$ spend most of their life cycle inside the tree. Therefore, conventional insecticides are only recommended to suppress active ambrosia beetle populations after removing and chipping infected/infested trees.

\section{In addition, several entomopathogenic fungi (Beauveria} bassiana) have been demonstrated to infect $\mathrm{AB}$, including immature stages developing inside the tree (Carrillo et al. 2015; Avery et al. 2018). AB infection inside the trees has been recorded up to 8 months after application of commercial formulations of entomopathogenic fungi (e.g., BotaniGard ${ }^{\circledR}$ and Mycotrol $\left.{ }^{\circledR}\right)$. However, because of the high cost of commercial formulations of entomopathogens, grove-wide applications of entomopathogenic fungi (e.g., BotaniGard ${ }^{\circledR}$ and Mycotrol $^{\circledR}$ ) are recommended only in months of increased $\mathrm{AB}$ activity (late winter-early spring).

\section{Light levels are significantly higher and $A B$ activity sig-} nificantly reduced in newly planted grove areas, in areas where trees have been recently stumped (trees cut to $4 \mathrm{ft}$ $[1.2 \mathrm{~m}]$ ), and in recently top-worked areas of the grove compared to highly shaded avocado orchards with dense canopies (Figure 5; D. Carrillo and J. Crane, unpublished data). Thus, implementing or reestablishing a pruning program to enhance light penetration within grove trees is recommended to reduce $\mathrm{AB}$ activity and new $\mathrm{LW}$ outbreaks. Alternatively, rejuvenating or top-working large trees to reestablish high light conditions in the grove may be an option (described in more detail below).

\section{Current Control Options and Mitigation Recommendations}

\section{General}

1. Promote tree health by optimizing fertilizer and irrigation practices as well as Phytophthora root rot and other disease management. Healthy trees are less susceptible to $\mathrm{AB}$ attack than root-rot-affected, nutrient-deficient, or drought-stressed trees (J. Crane, personal communication). Any stress (e.g., flooding, drought, freezing, other pathogens, etc.) causes avocado trees to become attractive to $\mathrm{AB}$.

2. Scout groves frequently to detect trees with early LW symptoms (i.e., green-leaf wilting). The importance of early detection should not be underestimated given the fast spread rate of the pathogen among adjacent trees through root grafts.

3. Rogue LW-affected trees immediately: uproot and chip/ shred the entire tree (roots, trunk, limbs, etc.). It is imperative that trees be uprooted to reduce transmission of the LW pathogen to adjacent trees. The more quickly LW-affected trees are detected and removed, the greater the chances that the pathogen has not moved to adjacent trees. Roguing also eliminates $\mathrm{AB}$ reproduction within the tree, helping to reduce their populations. Currently, tree removal and disposal costs have decreased significantly, thus reducing disease management costs.

\section{Prophylactic Fungicide Injections}

1. Prophylactically inject all grove trees with propiconazole $\left(\right.$ Tilt $\left.^{\circledR}\right)$ prior to a LW outbreak. If this is not possible, remove LW-symptomatic trees as above and inject all remaining healthy-appearing trees. Some loss of healthy-appearing trees may continue due to the spread of the pathogen prior to injections. These trees should be removed as soon as possible. Injected trees will need to be reinjected at a 12-to-24-month interval depending upon the rate of Tilt ${ }^{\circledR}$ used, AB activity (i.e., initiating new LW infestations), and existent LW pressure (i.e., how many new LW outbreaks occur) (Brooks Tropicals, personal communication).

2. When using Tilt ${ }^{\circledR}$, growers must have in their possession the Section 18 Emergency Exemption label; contact Jeff Wasielewski, UF/IFAS Extension Commercial Tropical Fruit Crops Agent (305-248-3311, ext. 227; jwasielewski@ ufl.edu). 


\section{Ambrosia Beetle Control}

1. Spray chipped/shredded wood twice with contact insecticide. Insecticides registered for use on avocado include Malathion, Danitol ${ }^{\circledR}$, Agri-Mek $^{\circledR}$ SC, Talstar ${ }^{\circledR}$ S, Hero $^{\circledR}$ (nonbearing trees only), Botanigard ${ }^{\circledR}$, and $\mathrm{Mycotrol}^{\circledR}$ (Beauveria bassiana).

2. Make two trunk and major limb directed applications (up to about $10 \mathrm{ft}[3 \mathrm{~m}]$ height from the ground) at a 14-day interval of a registered contact insecticide to healthy trees within a 1-acre (0.4 ha) area of the LW-affected removed tree.

3. During late winter-early spring, when $\mathrm{AB}$ populations and activity increase, apply two grove-wide applications of the mycoinsecticides BotaniGard ${ }^{\circledR} \mathrm{ES}$ or Mycotrol ${ }^{\circledR}$ (Beauveria bassiana) to suppress $\mathrm{AB}$ populations.

\section{Cultural Practices and Mitigation}

1. Maintain a pruning regimen to increase sunlight penetration and hours of high sunlight in avocado groves to suppress ambrosia beetle activity. This may be accomplished with mechanical pruning (i.e., hedging and topping equipment) or by selective pruning. Alternatively, trees may be stumped to 4 feet or so (rejuvenated) and top-worked to new cultivars.

2. Rejuvenate old, very tall/large avocado trees that have lost most of their lower canopy fruit production by cutting trees down to 4 (stumped) to 8 feet (hat-racked). Whitewash the trunks and major limbs to prevent sunburn of the sun-exposed trunk and major limbs. Trees will begin to refoliate and reestablish canopy within several months and may begin fruit production within 3 years or so. Alternatively, the new growth on these trees may be top-worked (grafted) with new avocado cultivars that may be more profitable. Again, fruit production may begin within 3 years or so.

3. Replant avocado trees lost to LW to increase future fruit production and maintain economic viability (Evans et al. 2010; Mosquera et al. 2015). Movement of the LW pathogen by tree-to-tree root grafting is not an issue in young trees because it takes many years for root grafts to form, young trees are not a preferred host of $A B$, and the high light exposure of the area around these trees depresses $\mathrm{AB}$ activity.

\section{Concluding Remarks}

Control of the LW pathogen-AB complex is challenging due to the potential for rapid root-graft transmission, new LW infestations caused by $\mathrm{AB}$ movement, and the difficulty and expense of current control tactics. Ongoing research is aimed at further understanding of the biology of the pathogen and secondary $\mathrm{AB}$ capable of transmitting the LW pathogen, epidemiology (spread dynamics of the disease), and development of more efficient control and mitigation tactics. As more information is developed, control recommendations will be revised.

\section{Acknowledgements}

The authors thank the following supporting entities: USDANIFA grant 2015-51181-24257: Laurel Wilt of Avocado: Management of an Unusual and Lethal Disease; University of Florida Institute of Food and Agricultural Sciences; the Florida Avocado Administrative Committee; UF/IFAS Extension Miami-Dade County; and Florida Department of Agriculture and Consumer Services, Division of Plant Industry.

\section{Literature Cited}

Avery, P. B., V. Bojorque, C. Gámez, R. E. Duncan, D. Carrillo, and R. D. Cave. 2018. "Spore Acquisition and Survival of Ambrosia Beetles Associated with the Laurel Wilt Pathogen in Avocados after Exposure to Entomopathogenic Fungi." Insects 9 (2): 49. http://dx.doi.org/10.3390/ insects 9020049

Campbell, A. S., R. C. Ploetz, and J. A. Rollins. 2017. “Comparing Avocado, Swamp Bay, and Camphor Tree as Hosts of Raffaelea lauricola Using a Green Fluorescent Protein (GFP)-Labeled Strain of the Pathogen.” Phytopathology 107: 70-74.

Carrillo, D., J. H. Crane, and J. E. Peña. 2013. “Potential of Contact Insecticides to Control Xyleborus glabratus (Coleoptera: Curculionidae), a Vector of Laurel Wilt Disease in Avocados." J. Econ. Entomol. 106 (6): 2286-2295.

Carrillo, D., R. E. Duncan, and J. E. Peña. 2012. "Ambrosia Beetles (Coleoptera: Curculionidae: Scolytinae) That Breed in Avocado Wood in Florida." The Fla. Entomologist 95 (3): 573-579.

Carrillo, D., R. E. Duncan, J. N. Ploetz, A. F. Campbell, R. C. Ploetz, and J. E. Peña. 2014. "Lateral Transfer of a Phytopathogenic Symbiont among Native and Exotic Ambrosia Beetles." Plant Pathology 63: 54-62. 
Carrillo, D., C. A. Dunlap, P. B. Avery, J. Navarrete, R. E. Duncan, M. A. Jackson, R. W. Behle, R. D. Cave, J. Crane, A. P. Rooney, and J. E. Peña. 2015. "Entomopathogenic Fungi as Biological Control Agents for the Vector of the Laurel Wilt Disease, the Redbay Ambrosia Beetle, Xyleborus glabratus (Coleoptera: Curculionidae)." Biological Control 81: 44-50.

Crane, J. H., E. A. Evans, D. Carrillo, R. C. Ploetz, and A. J. Palmateer. 2015. "The Potential for Laurel Wilt to Threaten Avocado Production is Real." ACTAS, Proceedings of the VIII Congreso Mundial de la Palta, Lima, Peru. 13-18 Sept. 2015.

Crane, J. H., R. C. Ploetz, T. White, G. C. Krogstad, T. Prosser, J. Konkol, and R. Wideman. 2015. "Efficacy of Three Microinfused Fungicides to Control Laurel Wilt on Avocado in Martin and Brevard Counties." Proc. Fla. State Hort. Soc. 128: 58-60.

Dreaden, T. J., A. S. Campbell, C. A. Gonzalez-Benecke, R. C. Ploetz, and J. A. Smith. 2016. "Response of Swamp Bay, Persea palustris, and Redbay, P. bornbonia, to Raffaelea spp. Isolated from Xyleborus glabratus." Forest Pathology 2017 (47): e12288. https://doi.org/10.1111/efp.12288

Evans, E. A., J. Crane, A. Hodges, and J. L. Osborne. 2010. "Potential Economic Impact of Laurel Wilt Disease on the Florida Avocado Industry." HortTechnology 20 (1): 234-238.

Evans, E. A., J. H. Crane, R. C. Ploetz, and F. H. Ballen. 2015. "Cost-Benefit Analysis of Area-wide Management of Laurel Wilt Disease in Florida Commercial Avocado Production Area." Proc. VIII Congreso Mundial de la Palta (Colombia; in Spanish). 467-470.

Fraedrich, S. W. 2008. "California Laurel Is Susceptible to Laurel Wilt Caused by Raffaelea lauricola." Plant Dis. 92: 1469.

Fraedrich, S. W., T. C. Harrington, R. J. Rabaglia, M. D. Ulyshen, A. E. Mayfield, III, J. L. Hanula, J. M. Eickwort, and D. R. Miller. 2008. "A Fungal Symbiont of the Redbay Ambrosia Beetle Causes a Lethal Wilt in Redbay and Other Lauraceae in the Southeastern United States." Plant Dis. 92: 215-224.

Fraedrich, S. W., T. C. Harrington, C. A. Bates, J. Johnson, L. S. Reid, G. S. Best, T. D. Leininger, and T. S. Hawkins. 2011. "Susceptibility to Laurel Wilt and Disease Incidence in Two Rare Plant Species, Pondberry and Pondspice." Plant. Dis. 95: 1056-1062.
Fraedrich, S. W., T. C. Harrinton, and G. S. Best. 2015. "Xyleborus glabratus Attacks and Systemic Colonization by Raffaelea lauricola Associated with Dieback of Cinnamomum camphora in the Southeastern United States." For. Path. 45: 60-70.

Hughes, M. A., K. Shin, J. Eickwort, and J. A. Smith. 2012. "First Report of Laurel Wilt Disease Caused by Raffaelea lauricola on Silk Bay in Florida." Disease Notes 96: 910.

Hughes, M. A., G. Brar, R. C. Ploetz, and J. A. Smith. 2013. "Field and Growth Chamber Inoculations Demonstrate Persea indica a Newly Recognized Host of the Laurel Wilt Pathogen, Raffaelea lauricola." Plant Health Progress 14 (1). https://doi.org/10.1094/PHP-2013-0814-02-BR

Hughes, M. A., A. Black, and J. A. Smith. 2014. "First Report of Laurel Wilt Caused by Raffaelea lauricola on Bay Laurel (Laurus noblis) in the United States." Plant Dis. 98: 1159.

Inch, S. E., and R. C. Ploetz. 2012. "Impact of Laurel Wilt, Caused by Raffaelea lauricola, on Xylem Function in Avocado, Persea americana." For. Path. 42: 239-245.

Inch, S., R. Ploetz, B. Held, and R. Blanchette. 2012. "Histological and Anatomical Responses in Avocado, Persea americana, Induced by the Vascular Wilt Pathogen, Raffaelea lauricola." Botany 90: 627-635.

Mayfield, A. E., III, M. MacKenzie, P. G. Cannon, S. W. Oak, S. Horn, J. Hwang, and P. E. Kendra. 2013. "Suitability of California Bay Laurel and Other Species as Hosts for the Non-native Redbay Ambrosia Beetle and Granulate Ambrosia Beetle." Agric. and Forest Entomology 15: 227-235.

Mayfield, A. E., III, and M. C. Thomas. 2006. “The Redbay Ambrosia Beetle, Xyleborus glabratus Eichhoff (Scolytinae: Curculionidae).” DACS-P-01651. Florida Department of Agriculture and Consumer Services, Division of Plant Industry. https://www.freshfromflorida.com/content/ download/66299/1600379/PEST_ALERT_-_Xyleborus_glabratus_-_Redbay_Ambrosia_Beetle.pdf

Menocal, O., P. E. Kendra, W. S. Montgomery, J. H. Crane, and D. Carrillo. 2018. "Vertical Distribution and Daily Flight Periodicity of Ambrosia Beetles (Coleoptera: Curculionidae) in Florida Avocado Orchards Affected by Laurel Wilt." J. Econ. Entomology 111 (3): 1190-1196. 
Mosquera, M., E. A. Edwards, and R. Ploetz. 2015. "Assessing the Profitability of Avocado Production in South Florida in the Presence of Laurel Wilt." Theoretical Economics Letters 5: 343-356.

Peña, J. E., J. H. Crane, J. L. Capinera, R. E. Duncan, P. E. Kendra, R. C. Ploetz, S. McLean, G. Brar, M. C. Thomas, and R. D. Cave. 2011. "Chemical Control of the Redbay Ambrosia Beetle, Xyleborus glabratus, and Other Scolytinae (Coleoptera: Curculionidae)." Fla. Entomol. 94 (4): 882-896.

Ploetz, R. C., J. E. Peña, J. A. Smith, T. J. Dreaden, J. H. Crane, T. Schubert, and W. Dixon. 2011a. "Laurel Wilt, Caused by Raffaelea lauricola, Is Confirmed in Miami-Dade County, Center of Florida's Commercial Avocado Production." Disease Notes 95 (12): 1589.

Ploetz, R. C., J. A. Smith, S. A. Inch, J. E. Peña, E. A. Evans, J. H. Crane, P. Kendra, J. Hulcr, L. Stelinski, and R. Schnell. 2011b. "Laurel Wilt: A Global Threat to Avocado Production." Proc. VII World Avocado Congress, Cairns, Australia.

Ploetz, R. C., J. M. Pérez-Martínez, J. A. Smith, M. Hughes, T. J. Dreaden, S. A. Inch, and Y. Fu. 2011c. "Responses of Avocado to Laurel Wilt, Caused by Raffaelea lauricola." Plant Pathology 61 (4): 801-808. https://doi. org/10.1111/j.1365-3059.2011.02564.x

Ploetz, R. C., J. M. Pérez-Martínez, E. A. Evans, and S. A. Inch. 2011d. "Toward Fungicidal Management of Laurel Wilt of Avocado." Plant Disease 95: 977-982.

Ploetz, R. C., and J. Konkol. 2013. "First Report of Gulf Licaria, Licaria trianda, as a Suspect of Laurel Wilt." Plant Dis. 97: 1248.

Ploetz, R. C., J. L. Konkol, J. M. Pérez-Martínez, and R. Fernandez. 2017. "Management of Laurel Wilt of Avocado, Caused by Raffaelea lauricola." Eur. J. Plant Pathol. 149: 133-143. https://doi.org/10.1007/s10658-017-1173-1

Thomas, M. C. 2010. "Entomology Specimen Report." E2020-1101-1. Gainesville, FL: Fla. Dept. Agric. and Consumer Services, Div. of Plant Industry.

US Forest Service. 2019. "Distribution of Counties with Laurel Wilt Disease by Year of Initial Detection." https://www.fs.usda.gov/Internet/FSE_DOCUMENTS/ fseprd571973.pdf 
Table 1. Mature avocado tree cultivars and their genetic background that have succumbed to the laurel wilt pathogen.

\begin{tabular}{|c|c|}
\hline Cultivar Name & Background \\
\hline Arue & WI \\
\hline Bernecker & WI \\
\hline Day & WI \\
\hline Donnie & WI \\
\hline Dupuis & WI \\
\hline Hardee & WI \\
\hline Peterson & WI \\
\hline Pollock & WI \\
\hline Russell & WI \\
\hline Simmonds & WI \\
\hline Waldin & WI \\
\hline Beta & G-WI \\
\hline Booth 7 & G-WI \\
\hline Booth 8 & G-WI \\
\hline Brooks Late & G-WI \\
\hline Buck II & G-WI \\
\hline Choquette & G-WI \\
\hline Hall & G-WI \\
\hline Loretta & G-WI \\
\hline Lula & G-WI \\
\hline Miguel & G-WI \\
\hline Monroe & G-WI \\
\hline Nadir & G-WI \\
\hline Nesbitt & G-WI \\
\hline Tonnage & G-WI \\
\hline Tower-2 & G-WI \\
\hline Wheeling & G-WI \\
\hline Brogdon & G-M-WI \\
\hline Marcus Pumpkin & G \\
\hline Winter Mexican & G-M \\
\hline Toni & $\mathrm{Nd}$ \\
\hline Jim Lapeck & $\mathrm{Nd}$ \\
\hline
\end{tabular}

